\title{
Acting Real: Testimony of Rachel Corrie on Stage
}

\section{Tugba Aygan}

Ataturk University

\begin{abstract}
In response to the chaotic atmosphere of the twentieth century, defined by an enormous scepticism about politics and media, theatre emerged out as a source of truth through plays compiled from spoken testimonies of real people, interviews, documents and recordings of real events and many other authentic materials. Named variably as theatre of the real, documentary theatre or verbatim theatre, those plays challenged their audiences into an inescapable confrontation with real events and serious issues around the world. Edited by the British actor and theatre director Alan Rickman and the Guardian journalist Katharine Viner, one of the key examples of verbatim theatre, My Name is Rachel Corrie, was premiered in April 2005 at Royal Court in London. Based on Israel-Palestine conflict, the play is constructed on the e-mails and diaries of an American peace-activist Rachel Corrie who was killed by an Israeli bulldozer in Gaza in 2003. After providing a history of documentary theatre, this paper discusses the controversial productions of My Name is Rachel Corrie as an example of testimony.
\end{abstract}

Keywords: My Name is Rachel Corrie, verbatim theatre, testimony, documentary theatre, Israeli-Palestinian Conflict

\section{Introduction}

A steadily increasing tendency for documented reality thanks to a strong desire to learn and to be informed have manifested itself in many forms in the contemporary world. Movie industry has adopted historical themes and more and more fiction writers have started to borrow from real life events while constructing their works. As aesthetician Arnold Hauser (2005) points out,

This tendency to the factual and the authentic-to the 'document'-is evidence not only of the intensified hunger for reality characteristic of the present age, of its desire to be well informed about the world, with an activistic ulterior motive, but also of that refusal to accept the artistic aims of the last century which is expressed in the flight from the story and from the individual, psychologically differentiated hero. (p.163)

In a world where the understanding of the real has been continually revised, reinvented and highly mediatised, this "hunger for reality" in Hauser's terms has led theatre practitioners to new paths for representing realities on the stage. Variably referred to as theatre of the real, verbatim theatre, factual theatre, docudrama, theatre of the witness, tribunal theatre, theatre of fact, nonfictional theatre and theatre as journalism, documentary theatre as an example of this tendency has come to the fore with the claim of representing the real objectively.

In her seminal essay "Bodies of Evidence" Carol Martin (2010) asserts that documentary theatre is "created from a specific body of archived material: interviews, documents, hearings, records, video, film, photographs, etc.' (p. 18) and marshals six main functions of the documentary theatre as,

1. To reopen the trials in order to critique justice... 2. To create additional historical accounts... 3. To reconstruct an event... 4. To intermingle autobiography with history... 5. To critique the operations of both documentary and fiction... 6 . To elaborate the oral culture of theatre and the theatricality of daily life... (p. 22)

Gaining prominence in the 60 s and 70 s due to social and political changes and strong suspicions about the objectivity of the media, documentary plays have turned into an alternative source of information, and documents used in the plays, in Peter Weiss' words, have become "segments of reality" which "are the only weapons against an untrustworthy news media" (Dawson, 1999, p. 15). Giving some thought to the contemporary issues in the world, they draw from real life people and 
events, specifically focusing on telling stories of marginalised and oppressed groups by virtue of their sexual orientation, race, class, gender, religion, and from significant incidents such as war trials, terrorist attacks, social and political upheavals as well as any kind of persecution in attempt to provide their audience with unadulterated facts and plain realities through authentic documents. Offering alternative perspectives other than mediatised ones, those plays aim at bringing controversial subjects on the table and providing a public forum over them.

Although the label itself is relatively new, documentary tradition has persisted throughout the theatre history. Written in 472 B.C. by Aeschylus, the Greek play The Persians is recognised as the earliest documentary play in the Western culture. Portraying the Battle of Salamis, The Persians is a fact-driven play that celebrates Greece's victory over Persians. According to Attilio Favorini (1995), Aeschylus himself was possibly a war veteran and "had seen the Persians with his own eyes" ( $p$. xiii). An older contemporary of Aeschylus, Phrynichus, first tragedian to introduce female masks, produced the tragedy The Capture of Miletus in 494 B.C. based on interviews with the soldiers in the Persian War by the same token. However, evoking a scandal, his play was banned and he was fined a thousand drachmas by the Athenians for reminding painful recollections of their friends' loss. (Rehm, 2017, p. 24)

Naming German playwright Georg Büchner's 1835 play Danton's Death (Dantons Tod) "a proto-documentary play in the modern sense" (Dawson, 1999, p. 1) as much of the dialogues of the play comes from primary sources and as it cites from key agents of the French Revolution, Gary Fisher Dawson places Danton's Death to the beginning of the inquiry in the field of modern documentary theatre. Following Büchner, in terms of the techniques used, and political concerns of the plays, documentary theatre owes a lot to the theatre of German theatre practitioners Erwin Piscator and Bertolt Brecht. When the term "documentary" first entered literature in 1926 with John Grierson's review about Robert Flaherty's documentary film Moana (1926) in The New York Sun, Brecht addressing Piscator's experiments also used the term 'documentary' and Piscator's mammoth revue, depicting Germany from the outbreak of First World War to the assassination of the German socialist and co-founder of the Spartacist League and the Communist Party of Germany, Karl Liebknecht, In Spite of Everything! (Trotz Alledem!) (1925) has been seen as the first real documentary attempt. Taking its name from a phrase used in Liebknecht's speech (Piscator, 1980, p. 70) the play constructed with montage of real news extracts, authentic recorded speeches, leaflets, slogans, photographs and film scenes from the First World War, henceforth hailed by Favorini (2008) as the "urtext of documentary theatre" (p. 74).

Another successful German representative of documentary theatre Heinard Kipphardt came to prominence with his 1964 play Matter of J. Robert Oppenheimer (In der Sache J. Robert Oppenheimer) which he formed out of 3000 pages' protocol of Cold War inquisition (Mason, 1977, p. 269). Reawakening a strong interest in documentary theatre, German playwright Rolf Hochhuth's The Deputy (Der Stellvertreter) was staged in 1963 and based on one of the major organisers of Holocaust, Nazi Lieutenant colonel Adolph Eichmann's trial. Believing in freedom of writer "which alone empowers him to give form to the matter" (Hochhuth, 1964, p. 288), Hochhuth refused to abide by the complete factual authenticity and freely invented scenes and characters for the play which still managed to remain loyal to actual history. Making use of court records, Investigation (Die Ermittlung) (1965) by the German playwright Peter Weiss was similarly based on documents of the 1964 Frankfurt War Crimes Trial on the murders in Auschwitz. Weiss proclaimed that in the play he aimed "to show the audience, in the greatest detail, exactly what happened [in Auschwitz]" (Gray, 1966, p. 108) which, among others, places the play in the heart of documentary theatre.

All of these German theatre practitioners have had a massive influence on British documentary tradition. Chronicling the First World War using the facts, statistics and documents of the time, in 1963 Joan Littlewood composed her Oh! What a Lovely War, one of the earliest English documentary plays. A harsh satirical attack on the war, the play is a combination of real documents, songs, dances and sketches. In a similar manner with Oh! What a Lovely War, Falkland Sound (1983) by Louise Page has set another early example of the British documentary tradition by dramatizing the Falklands War based heavily on Royal Navy supply officer David Tinker's letters. Following these landmarks, documentary theatre has flourished in British theatre.

Although the tendency to use authentic documents in the plays has generally been grouped under the umbrella term of documentary theatre, according to the type of documents they utilise, some plays may be subcategorised as verbatim theatre. Verbatim theatre, frequently used interchangeably with documentary theatre, has found its widest use in Britain, and as the name suggests, it is heavily predicated upon the exact words of real people collected from interviews, speeches, news, journals and testimonies with an aim, as Richard Norton Taylor suggests, "to uncover and establish the most accurate version of events" (Hammond \& Steward, 2008, p. 114). 
First coined by Derek Paget in his article titled "'Verbatim Theatre': Oral History and Documentary Techniques", verbatim theatre is defined by Paget (1987) himself as:

A form of theatre firmly predicated upon the taping and subsequent transcription of interviews with 'ordinary' people, done in the context of research into a particular region, subject area, issue, event, or combination of these things. The primary source is then transformed into a text which is acted, usually by the performers who collected the material in the first place. (p. 317).

The plays Paget refers to in his article are earlier forms of verbatim theatre by theatre practitioners such as Rony Robinson, Ron Rose and David Thacker who were highly indebted to the plays and theories of Bertolt Brecht and Erwin Piscator. One of these early verbatim theatre practitioners, Peter Cheeseman highlighted local issues in his plays which were based on interviews with and recordings of local people in the mid-sixties at Victoria Theatre in Stoke-on-Trent.

In the new millennium, due to global unrest across the world, verbatim theatre has enjoyed public recognition and remarkable increase in Britain by the productions of Tricycle Theatre, Out of Joint, 7:84 Theatre Company, Liverpool Everyman and Royal Court Theatre. A "rebuke to the British theatre for its drift towards less and less important subject matter" (Hare, 2015, p.77) in David Hare's words, the Guardian reporter Richard Norton-Taylor's The Colour of Justice (1999) and others such as Nuremberg (1996), Justifying War (2003); Hare's own plays such as Via Dolorosa (1998), The Permanent Way (2003), and Stuff Happens (2004); Robin Soan's A State Affair (2000), Talking to Terrorists (2005), The Arab-Israeli Cookbook (2004), Alecky Blythe's Come Out Eli (2002) and Cruising (2003) mark some of the epitomes of verbatim theatre.

One of the most contentious and debated matters of both the $20^{\text {th }}$ and the $21^{\text {st }}$ centuries, the Israel-Palestine conflict has also been a popular subject on the British stage. This never-ending plight has been treated in some documentary plays such as Hare's Via Dolorosa and its sequel Wall (2009) as well as Robin Soan's Arab-Israeli Cookbook. Edited by the Guardian journalist Katherine Viner and the British actor and theatre director Alan Rickman, My Name is Rachel Corrie (2003) is another popular verbatim play predicated on this ongoing conflict. The play, constructed by diary entries and emails of an American peace activist Rachel Corrie, premiered at the Royal Court Theatre on 7 April 2005 and won the Theatregoers' Choice Award for the year's Best New Play, also receiving the Best Director and the Best Solo Performance awards.

Rachel Corrie in her own words, "was born on April 10th, 1979 in Olympia, Washington, to her mother and father, Craig and Cindy, a brother Chris, a sister Sarah, and a very old cat named Phoebe." (Alan \& Viner, 2008, p. 5). She attended Capital High School, then The Evergreen State College where she became a member of a pro-Palestinian group called International Solidarity Movement (ISM) and then decided to go to Palestine. Just two months after she went to Palestine, Corrie was tragically crushed to death on 16 March 2003 by one of the Israeli bulldozers while trying to prevent it from demolishing Palestinians' houses. While other ISM members in the scene said the driver run over Corrie deliberately, Israeli Defence Forces claimed that it was "a regrettable accident" (BBC News, 28 Aug 2012). The Corrie family sued the Israeli Ministry of Defence for negligence, and following nearly a three-year trial, the court decided that it was an accident for which the state was not responsible. (Sherwood, 2012)

After its first production at the Royal Court, subsequent home runs in the West End and across the UK, My Name is Rachel Corrie was supposed to transfer to Broadway. Yet, New York Theatre Workshop withdrew its upcoming production of the play because of the 'political climate' of the time and due to their serious concerns about the reactions of the Jewish community. Cancellation of the play generated heated media debates mostly denouncing the act as censorship. Artistic director of the theatre, James Nicola, stated,

In our pre-production planning and our talking around and listening in our communities in New York, what we heard was that after Ariel Sharon's illness and the election of Hamas, we had a very edgy situation. We found that our plan to present a work of art would be seen as us taking a stand in a political conflict, that we didn't want to take. (Borger, 2006)

Rickman on the other hand declared "This is censorship born out of fear, and the New York Theatre Workshop, the Royal Court, New York audiences - all of us are the losers." (Borger, 2006). Following New York Theatre Workshop, a month later, Plantation's Mosaic Theater dropped the play from its line-up as "an impassioned, vocal minority strongly objected to the play" (Dolen, 2007). However, despite all the cancellations, the play was eventually staged Off-Broadway on October 15, 2006 at the Minetta Lane Theatre followed by its successful run at the Seattle Repertory Theatre in March-April 2007. 
A decade after Corrie's death in 2013, the play was revived with a production in Hebrew by Jerusalem Khan Theatre. While some critics hailed the play as "a testimony to innocent lives lost in the crossfire of the Israel-Palestinian conflict" (Rubin, 2013), deputy mayor of Jerusalem David Hadari initiated a campaign to halt public funding to the theatre, and wrote a letter to the authorities in the municipality dubbing Rachel Corrie an "anti-lsrael tourist" and stating that following her accidental death, they "as a state don't need to acknowledge or appreciate her" (Rubin, 2013). The campaign, however, was rejected by the mayor of Jerusalem Nir Barkat who stated as a representative of the government he was "prevented by law from interfering in the freedom of expression" (Rubin, 2013). Director Ari Remez, in response, invited those criticising the play to see it saying "lt's a pity that the deputy mayor, just as MK Orit Strouk before him, is hurrying to judge the play as inciting without even seeing it. They are both most welcome to come and see the play first to see what it's all about" (Kaufman, 2013).

The play received exceptionally polarized reactions due to its touch upon delicate matters. Some critics praised it as "a remarkably moving 90-minute solo piece about human dignity and suffering," (Fischer, 2005) while newspapers reviewed it as "funny passionate, bristling with idealism and luminously intelligent" (Time Out), "Heartbreaking urgency" (The New York Times), "Deeply authentically human" (USA Today). The Guardian asserted "Theatre can't change the world. But what it can do, when it's as good as this, is to send us out enriched by other people's passionate concerns". Some others, however, commented on it as "a slight piece, worthy enough for a minor night of theatre if seen in terms of its considerable limitations, but profoundly unsatisfying, even retrograde, if regarded as a complex realization of either the art of monologue or the mission of 'progressive' theatre." (Davies, 2007, p. 27). Carol Martin (2009) also commented on the play as a "partial story" as it fails to include the Israeli side while giving voice to Palestinians. (p. 76)

Both Rachel Corrie's death and the play attracted a huge media attention. A week after Rachel's death, The Guardian journalist Sandra Jordan wrote the following lines, commenting on the amount of media and public interest in Rachel's death on the one hand, and hundreds of Palestinians whose death largely go unreported on the other:

On the night of Corrie's death, nine Palestinians were killed in the Gaza Strip, among them a four-year-old girl and a man aged 90. A total of 220 people have died in Rafah since the beginning of the intifada. Palestinians know the death of one American receives more attention than the killing of hundreds of Muslims. (23 March 2003)

Palestinians were not the only ones who knew that, Rachel was also aware of the fact that going to Palestine to live there was never equal to a Palestinian's experience, as her life was not equal to theirs. Foreshadowing the grim reality Jordan points out, Rachel says,

Nothing could have prepared me for the reality of the situation here. You can't just imagine it unless you see it. And even then your experience is not at all the reality: what with the difficulties the Israeli army would face if they shot an unarmed US citizen, the fact that I have the option of leaving. (Rickman \& Viner, 2005, p. 29)

She knew that she was privileged and had options. However, she chose to stay, writing to her mother, "I want to write and I want to see. And what would I write about if I only stayed within the doll's house, the flower-world I grew in?" (Rickman \& Viner, 14). The thought of leaving Palestine stirred feelings of unease in her as she states at the end of the play: "When I come back from Palestine I probably will have nightmares and constantly feel guilty for not being here, but I can channel that into more work. Coming here is one of the better things l've ever done" (Rickman \& Viner, p. 50).

Although Rachel struggled even more and could never make it home, she has continued to talk about Palestine and its people after she died. As David Hare asserts verbatim theatre aims to give "voice to voiceless" (Heddon, 2008, p. 128) as well as standing out as a reaction to misinformation and the mass media. My Name is Rachel Corrie becomes this voice. It gives voice to Rachel which turns into the voice of hundreds of dead people and millions living under wretched conditions, whose death and continuing suffering don't get enough coverage all over the world. As a common feature of verbatim plays, the play uses Rachel Corrie's testimony through which she speaks for those voiceless people after bearing witness to their lives. She witnesses and chooses to speak for "the children with tank-shell holes in their wall... surrounded by towers, tanks and now a giant metal wall... ${ }^{1}$ A city of 140.000 people, $60 \%$ of whom are refugees - many twice or three times refugees"

\footnotetext{
${ }^{1}$ Here, Corrie refers to Israeli West Bank wall, a highly controversial separation barrier between Israel and the West Bank, $85 \%$ of which running not along the official border Green Line but in the West Bank. While Israel claims it is a security barrier against terrorism Palestine calls it Apartheid Wall.
} 
(Rickman \& Viner, p. 29), and while witnessing Palestinian life under Israeli occupation with demolitions, checkpoints, armed warfare and economic destitution, she expresses her admiration to their resistance as "I am amazed at their strength in defending such a large degree of humanity against the incredible horror occurring in their lives and against the constant presence of death. I think the word is dignity" (Rickman \& Viner, p. 35).

Although the play is criticised for falling short of giving the whole picture by excluding suicide bombings and tunnels dug from Egypt to Gaza to smuggle weapons and food for terrorist groups, Rachel, in fact, straightforwardly raises some questions taking a clear political stance,

So when someone says that any act of Palestinian violence justifies Israel's actions not only do I question that logic in light of international law and the right of people to legitimate armed struggle in defence of their land and families; not only do I question that logic in light of the fourth Geneva Convention which prohibits collective punishment, prohibits the transfer of an occupying country's population into an occupied area, prohibits the expropriation of water resources and the destruction of civilian infrastructure such as farms; not only do I question that logic in light of the notion that fifty-year old Russian guns and homemade explosives can have any impact on the activities of one of the world's largest militaries, backed by the world's only superpower, I also question that logic on the basis of common sense (Rickman \& Viner, p. 48).

She also warns her mother against talking about "the cycle of violence, or 'eye for an eye'" as it would be "perpetuating the idea that the Israeli-Palestinian conflict is a balanced conflict, instead of the national liberation struggle of a largely unarmed people against the fourth most powerful military in the world" (Rickman \& Viner, p.12).

"At their best [verbatim plays] enable their audiences to undertake a collective act of bearing witness. They replay political events or spoken testimony in order to retrieve a sense of the complexity of issues that have been too easily turned into digestible headlines" (p. 371). Chris Megson (2005) asserts that in raising the problems of Palestinians into visibility Rachel's testimony turns its audience into witnesses and compels "an ethical responsibility to testify" (Marcus, 1994, p. 213). Presenting first-hand real life experiences, it prompts the audience to reconsider what is happening around the world, and intends to foster a new understanding of the Israeli-Palestine conflict by opening up new perspectives.

Although she bears witness to such atrocities that make her question her "fundamental belief in the goodness of human nature" (Corrie, 27 Feb 2003) and those atrocities, wars, hunger are still going on, the video at the end of the play featuring ten-year-old Rachel Corrie giving a speech calling for peace and ending hunger in the world at Fifth Grade Press Conference on World Hunger, instils hope for constructing a meaningful future. Rachel may be gone but her enduring words give hope for the possibility of change and her testimony calls for action.

\section{Bibliography}

[1] Davies, W. (2007). Art and Politics Psychoanalysis, Ideology, Theatre. London: Pluto Press.

[2] Derbyshire, H., Hodson, L. (2008). Performing Unjustice: Human Rights and Verbatim Theatre. Law and Humanities, 2, pp. 191-211.

[3] Eakin, P. (1999). How Our Lives Become Stories: Making Selves. Ithaca, NY: Cornell University Press.

[4] Favorini, A. (1995). Voicings: ten plays from the documentary theatre. Hopewell, NJ: Ecco Press.

[5] Favorini, A. (2008). Memory in Play: From Aeschylus to Sam Shepherd. New York: Palgrave Macmillan.

[6] Fisher Dawson, G. (1999). Documentary Theatre in the United States: An Historical Survey and Analysis of Its Content, form and Stagecraft. Greenwood Press: London.

[7] Gray, P. (Fall 1966). A Living World: An Interview with Peter Weiss. Tulane Drama Review II, No.I.

[8] Hammond, W., Steward D. (2008). Verbatim Verbatim: Contemporary Documentary Theatre. London: Oberon Books.

[9] Hare, D. (2005). Obedience, Struggle and Revolt: Lectures on Theatre. London: Faber \& Faber.

[10] Hauser, A. (2005). The Social History of Art, Volume IV: Nationalism, Impressionism and the Film Age. London: Routledge.

[11] Heddon, D. (2008). Autobiography and Performance. Hampshire: Palgrave Macmillan.

[12] Hochhuth, R. (1964). The Deputy. New York: Grove Press.

[13] Marcus, L. (1994). Auto/Biographical Discourses. Manchester: Manchester University Press. 
[14] Martin, C. (2009). Living Simulations: The Use of Media in Documentary in the UK, Lebanon and Israel. A. Forsyth \& C. Megson (eds). Get Real: Documentary Theatre Past and Present. Hampshire: Palgrave Macmillan, pp. 74-90.

[15] Martin, C. (2010). Bodies of Evidence. Dramaturgy of the Real on the World Stage. London: Palgrave Macmillan.

[16] Mason, G. (Fall 1977). Documentary Drama from the Revue to the Tribunal. Modern Drama, Volume 20, Number 3, pp. 263-277.

[17] Megson, C. (Fall 2005). 'This is all theatre': Iraq Centre Stage. Contemporary Theatre Review, pp. 369-371.

[18] Piscator, E. (1980). The Political Theatre. H. Rorrison (trans.). London: Eyre Methuen.

[19] Rehm, R. (2017). Understanding Greek Tragic Theatre. London, New York: Routledge.

\section{Internet Resources}

[20] BBC News, (28 Aug, 2012). http://www.bbc.com/news/world-middle-east-19395651

[21] Borger, J. (28 Feb 2006). Rickman slams 'censorship' of play about US Gaza activist. Retrieved April 10, 2017, from

[22] https://www.theguardian.com/world/2006/feb/28/usa.israel

[23] Corrie, R. (27 February 2003). E-mail to her mother. Rachel's Letters. Retrieved April 18, 2017, from

[24] http://ifamericaknew.org/download/rachels_letters.pdf

[25] Dolen, C. (3 April 2007). Theater Won't Stage Controversial Drama. Retrieved April 10, 2017, from

[26] http://www.inminds.com/article.php?id=10063

[27] Fischer, P. (14 April 2005). My Name Is Rachel Corrie. British Theatre Guide. Retrieved April 8, 2017, from

[28] http://www.britishtheatreguide.info/reviews/rachelcorrie-rev.

[29] Jordan, S. (23 March 2003). Making of a Martyr. The Guardian. Retrieved April 15, 2017, from

[30] https://www.theguardian.com/world/2003/mar/23/internationaleducationnews.students

[31] Kaufman, A. (1 July 2013). Jerusalem deputy mayor: Defund theater showing Rachel Corrie play. Retrieved April 12, 2017, from

[32] https://972mag.com/jerusalem-deputy-mayor-defund-theater-showing-rachel-corrie-play/74840/

[33] Rubin, S. (5 August 2013). Jerusalem Theater Revives Rachel Corrie's controversial Memory. Retrieved April 10, 2017, from

[34] http://www.csmonitor.com/World/Middle-East/2013/0805/Jerusalem-theater-revives-Rachel-Corrie-scontroversial-memory

[35] Sherwood, H. (27 August 2012). Rachel Corrie death: struggle for justice culminates in Israeli court. Retrieved April 12, 2017, from

[36] https://www.theguardian.com/world/2012/aug/27/rachel-corrie-death-israel-verdict 